\title{
Remembering Professor Heinz Kimmerle
}

\author{
PIUS M. MOSIMA \\ Higher Teachers’ Training College, University of Bamenda, Cameroon (piusmosima@yahoo.com)
}

German born Professor Heinz Kimmerle (1930-2016), was chair of intercultural philosophy at the philosophical faculty, Erasmus University Rotterdam, in the Netherlands from 1990-1995. He will be best remembered for his attempts to highlight African contributions in the field of intercultural philosophical studies. His struggle to move from the North Atlantic hegemonic position to the recognition of the validity, global relevance, and applicability of African knowledge systems in a bid to cross-fertilize them with established academic philosophy is one of those giant strides he undertook. Intercultural philosophy, as conceived by Kimmerle, investigates the myriad aspects of its central theme, namely interculturality. It is that branch of philosophy that was explicitly established in order to address the globalization of difference. Intercultural philosophy seeks to develop a discourse that will allow for a discussion of all philosophical problems from an intercultural perspective. It does this by a theoretical reflection on concepts like culture, cultural diversity, cultural relativism, multiculturality, power, hermeneutics, and dialogue. Intercultural philosophy, with the use of such concepts, critically explores the conditions under which we can talk of interculturality. It seeks to prevent any philosophical position from assuming an absolute position. Kimmerle, with other intercultural philosophers such as Ram Adhar Mall, Dieter Lohmar, Franz-Martin Wimmer and Wim van Binsbergen, opines that there are many philosophical traditions of significance in all regions of the world, rather than just a few or one. Kimmerle was very critical of the tendency in Western philosophy to think in rather totalizing and universalizing concepts. Such a tendency excludes other philosophical traditions around the globe. He argued that the meeting of different cultural orientations and philosophical tendencies calls for an intensive and qualified discourse on the part of all concerned.

After spending many years of research at the Hegel Archive in Germany, he took cognizance of Hegel's well-known racist claims on Africa. Hegel's assertions concerning the question of philosophy and culture in Africa could be summed up in seven theses: Africa is static, Africa is primitive, Africa is without history, Africa is profligate, Africa is savage, Africa has no proper philosophy, and Africa is a culturally homogeneous continent. Hegel's statements above remain an example of European self-affirmation in opposition to other cultures and philosophies, and ushered in a kind of elaborate rationalization of European ethnocentrism with claims to universality and objectivity. This racist and ethnocentric tendency influenced philosophers like Kant, Voltaire, Hume, Rousseau and an anthropologist like Lucien Lévy-Brühl.

Heinz Kimmerle refused to be a self-imposed prisoner of such Eurocentrism, but combined, blended and transgressed his Euro-cultural orientation and tried to explore the relation between his own and the African one. His critical reading of Hegel combined with the dialectical elements in hermeneutics with the reading of Schleiermacher, Marx and especially Derrida's philosophy of difference, enabled him to explore an intercultural philosophy with special focus on Africa. In this regard, he engaged in dialogues with African philosophers like Mogobe Ramose, Kwame Gyekye, Valentin Yves Mudimbe, Kwasi Wiredu and Henry Odera Oruka. He also crossed cultural boundaries through his numerous teaching and research visits to countries like Ghana, Ivory Coast, Kenya, Mali, Nigeria, Senegal, South Africa and Tanzania. In 1997, he was very instrumental in

Journal of World Philosophies 1 (Winter 2016):162-163

Copyright (C) 2016 Pius M. Mosima.

e-ISSN: 2474-1795 • http://scholarworks.iu.edu/iupjournals/index.php/jwp • doi: 10.2979/jourworlphil.1.1.16 
establishing the Department of Philosophy at the University of Venda in South Africa. Professor Kimmerle used these encounters with his African colleagues to set an intercultural philosophical framework for the construction of African knowledge systems. Even when he retired from his Chair at Rotterdam in 1995, African students studied and took PhDs under the supervision of his successor Professor Wim van Binsbergen.

As an intercultural philosopher, Heinz Kimmerle kept a critical distance from racist conclusions about Africa. He explored a new dimension of philosophy with special focus on intercultural dialogue, which invites us to go beyond our biases and stereotypes in different cultural contexts. He engaged in a critical reflection on the North Atlantic-dominated, hegemonic context in which African knowledge production takes place. In this way, he tried to formulate a radical Africanist counter-hegemonic alternative and also explore the possibilities for an intercultural production of knowledge, which situates itself in a field of tension between North Atlantic knowledge systems and the African ones. Kimmerle did this by studying the African life-worlds, their cosmologies and symbolic systems. He used proverbs, myths, legends and folk songs (the artistic and poetical aspect of human life a la Nietzsche) to counter Hegel's claims of these sources as being a 'bleak consciousness' of a 'bleak people.'

His thoughts will continue to inspire global philosophy with modes of thought which might help fertilize both the African and the North Atlantic traditions of philosophy in preparation for a global philosophy for the third millennium. His insistence on deconstructing North Atlantic knowledge production about African social and cultural realities, the need to recognize African knowledge systems and the necessity to cross cultural boundaries in a bid to celebrate our shared, common humanity remains major challenges for the future of this global philosophy.

Pius M. Mosima teaches Philosophy at the Higher Teachers' Training College, University of Bamenda; and is vice Country Director in charge of Research and Programs at the Benchmark Institute for Research and Development (BIRD) Yaoundé, Cameroon. He studied Philosophy at the Erasmus University Rotterdam (The Netherlands) under the supervision of Professor Wim van Binsbergen who succeeded Professor Heinz Kimmerle to that Chair in 1998. However, when Professor Wim van Binsbergen retired from that Chair in 2012, Mosima finally defended his thesis at Tilburg University (The Netherlands), where his co-supervisor, Professor Walter van Beek still had PhD conferment rights. Mosima is the author of Pbilosophic Sagacity and Intercultural Philosophy: Beyond Henry Odera Oruka (Tilburg: Dissertations in Language and Culture Studies, 2016). His research interests include: African /intercultural Philosophy; Globalization and Culture; Moral and Political Philosophy; Political Sociology and Anthropology; Citizenship and Development Studies; Gender Studies and Bioethics.

Journal of World Philosophies 1 (Winter 2016):162-163 